\title{
Five-year cognitive outcomes: Surgical effects or natural progression of vascular disease
}

\author{
John W. Hammon, Jr, MD, and David A. Stump, PhD
}

\section{See related article on page} 1206.
From the Department of Cardiothoracic Surgery, Wake Forest University School of Medicine, Winston-Salem, NC.

Received for publication Oct 27, 2006; accepted for publication Nov 2, 2006.

Address for reprints: John W. Hammon, Jr, MD, Department of Cardiothoracic Surgery, Wake Forest University School of Medicine, Medical Center Blvd, WinstonSalem, NC 27157-1096 (E-mail: jhammon@ wfubmc.edu).

J Thorac Cardiovasc Surg 2007;133:1133-4 0022-5223/\$32.00

Copyright (C) 2007 by The American Association for Thoracic Surgery

doi:10.1016/j.jtcvs.2006.11.032
7 he article "Neuroprotective effect of mild hypothermia in patients undergoing coronary artery surgery with cardiopulmonary bypass: Five-year follow-up of a randomized trial," published in this issue, ${ }^{1}$ is a follow-up to an excellent article written by the same authors in $2001,{ }^{2}$ which demonstrated that mild hypothermia applied to patients undergoing coronary artery bypass grafting $(\mathrm{CABG})$ for the entire operative course has a significant protective effect against early neurocognitive deficits. Mild hypothermia was the subject of another article from this group as being associated with better short-term outcomes. ${ }^{3}$ These studies and others point out a very important adjunct in treating patients on cardiopulmonary bypass with coronary disease.

The proposed mechanism of action is the reduction in the brain's metabolic rate and concomitant decrease in brain blood flow. Less brain blood flow reduces the potential embolic load. Hypothermia also reduces the volume of ischemic tissue undergoing necrosis or apoptosis.

In the present article, the authors sought to prove that the protective effect of hypothermia lasted through the early postoperative phase out to 5 years. Unfortunately, because of dropouts, the statistical power was weak: 109 of 131 patients initially studied had all four testing visits, further reducing the size of the randomized groups. The good news was that $48 \%$ of the total group had deficits at 1 week postoperatively but only 31 (28\%) of the 109 had deficits at 5 years.

Regrettably, there was a trend but no significant difference at 5 years between the hypothermic and normothermic groups. Because they could not prove that mild hypothermia had a lasting effect, the authors have chosen to focus solely on the importance of the early postoperative decline in the entire group as a predictor of late decline. This phenomenon has also been the subject of a recent article from Duke that hypothesized that patients with early cognitive decline after surgery, which then disappeared within several months, were more likely to be cognitively impaired at 5 years. ${ }^{4}$ Cardiopulmonary bypass and surgery were implicated in both early and late dysfunction.

Like the group at Johns Hopkins, we believe that this is an improper interpretation of the data. ${ }^{5}$ It is widely known that patients with several risk factors for atherosclerosis will do more poorly on early and late neurocognitive studies. ${ }^{6}$ In the present article, the group of patients with both early and late declines had poorer baseline performance in neurocognitive studies, less education, and more evidence of comorbid factors such as renal insufficiency. Given that one third to one half of patients undergoing $\mathrm{CABG}$ have magnetic resonance imaging (MRI) evidence of a cerebral infarction before surgery, ${ }^{7}$ it is highly likely that those patients with higher comorbidities had a greater atherosclerotic burden. Thus they were more likely to have events, occurring between 3 months and 5 years, that would be unrelated to cardiopulmonary bypass or surgery. 


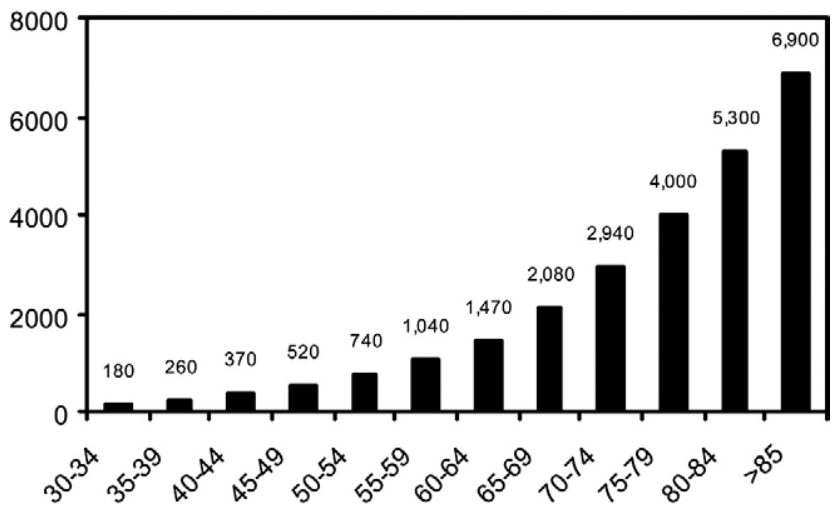

Figure 1. Annual rate of persons with first silent stroke by age (per 100,000 persons). (From Leary MC, Saver JL. Annual incidence of first silent stroke in the United States. Cerebrovasc Dis. 2003;16:280-5. Published with the permission of S. Karger AG, Basel.)

A recent study performed at the University of California at Los Angeles ${ }^{8}$ estimated the number of Americans who have new MRI-detectable infarcts each year based on age. Approximately $3 \%$ to $5 \%$ of persons in their 70 s will have a new infarct each year. In the patients undergoing $\mathrm{CABG}$, if they had no cardiac procedure, the estimated rate of first-time neurologic events would be $10 \%$ to $15 \%$. After the first infarct, the probability of a second is much greater; therefore, in the $\mathrm{CABG}$ population the event rate would be much higher.

Thus, it is not surprising that in this current article or in the Duke study, patients with early deficits that disappear at 3 months are more likely to have a late deficit than those patients who had no early decline. Furthermore, surgery or cardiopulmonary bypass should not be implicated as a cause of the 5-year decline in cognition any more than the patient's disease. This point is strengthened by data from a recent study from the United Kingdom. ${ }^{9}$ Investigators used MRI to determine the incidence of new brain infarcts in a group of patients having CABG surgery. New brain infarcts were found in $31 \%$ of patients between 3 months and 1 year.
What then can be done to improve the outcome in this patient group so prone to cerebral infarct (Figure 1)? Müllges and associates ${ }^{10}$ have recently reported follow-up studies on a group of CABG patients who had rigid control of atherosclerosis risk factors during the 5-year study period. Although substantially higher immediately postoperatively, cognitive decline was present in only $13 \%$ of their group at 5 years, suggesting that long-term cognitive outcome can be modified with appropriate medical management. These conclusions have important implications for postoperative patient management and should be verified in larger, better controlled studies.

\section{References}

1. Nathan HJ, Rodriguez R, Wozny D, Dupuis J-Y, Rubens FD, Bryson GL, et al. Neuroprotective effect of mild hypothermia in patients undergoing coronary artery surgery with cardiopulmonary bypass: five-year follow-up of a randomized trial. J Thorac Cardiovasc Surg. 2007;133:1206-11

2. Nathan HJ, Wells GA, Munson JL, Wozny D. Neuroprotective effect of mild hypothermia in patients undergoing coronary artery surgery with cardiopulmonary bypass: a randomized trial. Circulation. 2001; 104(suppl I):185-91

3. Nathan HJ, Parlea L, Dupuis JY, Hendry P, Williams KA, Rubens FD, et al. Safety of deliberate intraoperative and postoperative hypothermia for patients undergoing coronary artery surgery: a randomized trial J Thorac Cardiovasc Surg. 2004;127:1270-5.

4. Newman MF, Kirchner JL, Phillips-Bute B, Gaver V, Grocott H, Jones $\mathrm{RH}$, et al. Longitudinal assessment of neurocognitive function after coronary artery bypass surgery. $N$ Engl J Med. 2001;344:395-402.

5. Selnes OA, Grega MA, Borowiz LM Jr, Royall RM, McKhann GM, Baumgartner WA. Cognitive changes with coronary artery disease: a prospective study of coronary artery bypass graft patients and nonsurgical controls. Ann Thorac Surg. 2003;75:1377-86.

6. Ernest CS, Murphy BM, Worcester MUC, Higgins RO, Elliott PC, Goble AJ, et al. Cognitive function in candidates for coronary bypass surgery. Ann Thorac Surg. 2006;82:812-8.

7. Goto T, Baba T, Yoshitake A, Shibata Y, Ura M, Sakata R. Craniocervical and aortic atherosclerosis as neurologic risk factors in coronary surgery. Ann Thorac Surg. 2000;69:834-40.

8. Leary MC, Saver JL. Annual incidence of first silent stroke in the United States. Cerebrovasc Dis. 2003;16:280-5.

9. Kohn A. Magnetic resonance imaging registration and quantification of the brain before and after coronary artery bypass graft surgery. Ann Thorac Surg. 2002;73:S363-5.

10. Müllges W, Babin-Ebell J, Reents W, Toyka KV. Cognitive performance after coronary artery bypass grafting: a follow-up study. $\mathrm{Neu}$ rology. 2002;59:741-3. 